\title{
Novel Water-Soluble Near-Infrared Cyanine Dyes: Synthesis, Spectral Properties, and Use in the Preparation of Internally Quenched Fluorescent Probes
}

Cédric Bouteiller, ${ }^{\dagger, \uparrow}$ Guillaume Clavé, ${ }^{\dagger,+\pi}$ Aude Bernardin, ${ }^{\dagger, \uparrow}$ Bertrand Chipon, ${ }^{\dagger,+}$ Marc Massonneau, ${ }^{\dagger}$ Pierre-Yves Renard, ${ }^{*}, \dagger$ and Anthony Romieu ${ }^{*}, \dagger$

IRCOF, Equipe de Chimie Bio-Organique, UMR 6014 CNRS, INSA de Rouen et Université de Rouen, 1, rue Lucien Tesnières, 76131 Mont-Saint-Aignan Cedex, France and QUIDD, Technopôle du Madrillet, 50, rue Ettore Bugatti, 76800 Saint-Etienne du Rouvray, France.

* pierre-yves.renard@univ-rouen.fr or anthony.romieu@univ-rouen.fr. Phone: +33-2-35-5224-14 (or 24-15). Fax: +33-2-35-52-29-59.

† IRCOF, Equipe de Chimie Bio-Organique

$¥$ QUIDD

I These authors contributed equally to this work

\section{SUPPORTING INFORMATION}

S1 Experimental section : Synthesis of thiol-reactive NIR5.5-1 derivative 24 and fluorogenic NIR5.5-1/NIR7.0-2 hexapeptide 25.

S2 MALDI-TOF mass spectrum of probe $\mathbf{2 5 .}$

S3 Absorption spectra of probe $\mathbf{2 5}$ in PBS and EtOH.

S4 Emission (Ex. $\lambda=670$ or $750 \mathrm{~nm}$ ) spectra of probe 25 in PBS and EtOH.

S5 Emission (Ex. $\lambda=780 \mathrm{~nm}$ ) spectra of probe 19 in PBS and DMSO.

S6 Fluorescence emission time course of probe 19 with BSA protein in caspase assay buffer. 
-S1- Experimental section : Synthesis of thiol-reactive NIR5.5-1 derivative 24 and fluorogenic NIR5.5-1/NIR7.0-2 hexapeptide 25.

HPLC separations. Several chromatographic systems were used for the analytical experiments and the purification steps. Each one of these systems was optimised in order to improve separation conditions.

System A: RP-HPLC (Thermo Hypersil GOLD C 18 column, $5 \mu \mathrm{m}, 4.6$ x $150 \mathrm{~mm}$ ) with $\mathrm{CH}_{3} \mathrm{CN}$ and $0.1 \%$ aq. trifluoroacetic acid (aq. TFA, $0.1 \%$, v/v, $\mathrm{pH} 2.0$ ) as the eluents, at a flow rate of $1 \mathrm{~mL} / \mathrm{min}$, with the following gradients:

A1 : [100\% TFA (5 min), linear gradient from 0 to $20 \%$ (8 $\mathrm{min})$ and 20 to $80(27 \mathrm{~min})$ of $\left.\mathrm{CH}_{3} \mathrm{CN}\right]$. Dual UV-Visible detection was achieved at 260 and $680 \mathrm{~nm}$.

A2 : [100\% TFA (5 min), linear gradient from 0 to $40 \%$ (20 min) and 40 to $80 \%$ (40 $\mathrm{min}$ ) of $\left.\mathrm{CH}_{3} \mathrm{CN}\right]$. Triple UV-Visible detection was achieved at 260, 680 and $750 \mathrm{~nm}$.

System B: RP-HPLC (Waters XTerra MS C 18 column, $5 \mu \mathrm{m}, 7.8 \times 100 \mathrm{~mm}$ ) with $\mathrm{CH}_{3} \mathrm{CN}$ and $0.1 \%$ aq. TFA as the eluents, at a flow rate of $2.5 \mathrm{~mL} / \mathrm{min}$, with the following gradients:

$\mathrm{B} 1$ : [ $85 \%$ TFA (5 min), linear gradient from 15 to $60 \%$ (45 min) of $\mathrm{CH}_{3} \mathrm{CN}$ ]. UV detection was achieved at $260 \mathrm{~nm}$.

B2 : [ $80 \%$ TFA (5 min), linear gradient from 20 to $80 \%$ (60 min) of $\mathrm{CH}_{3} \mathrm{CN}$ ]. UV detection was achieved at $260 \mathrm{~nm}$.

B3 : [ $85 \%$ TFA (5 min), linear gradient from 15 to $35 \%$ (10 min) and 35 to $80 \%$ (45 $\mathrm{min}$ ) of $\mathrm{CH}_{3} \mathrm{CN}$ ]. UV detection was achieved at $260 \mathrm{~nm}$.

\section{Preparation of thiol-reactive NIR5.5-1 derivative (24).}
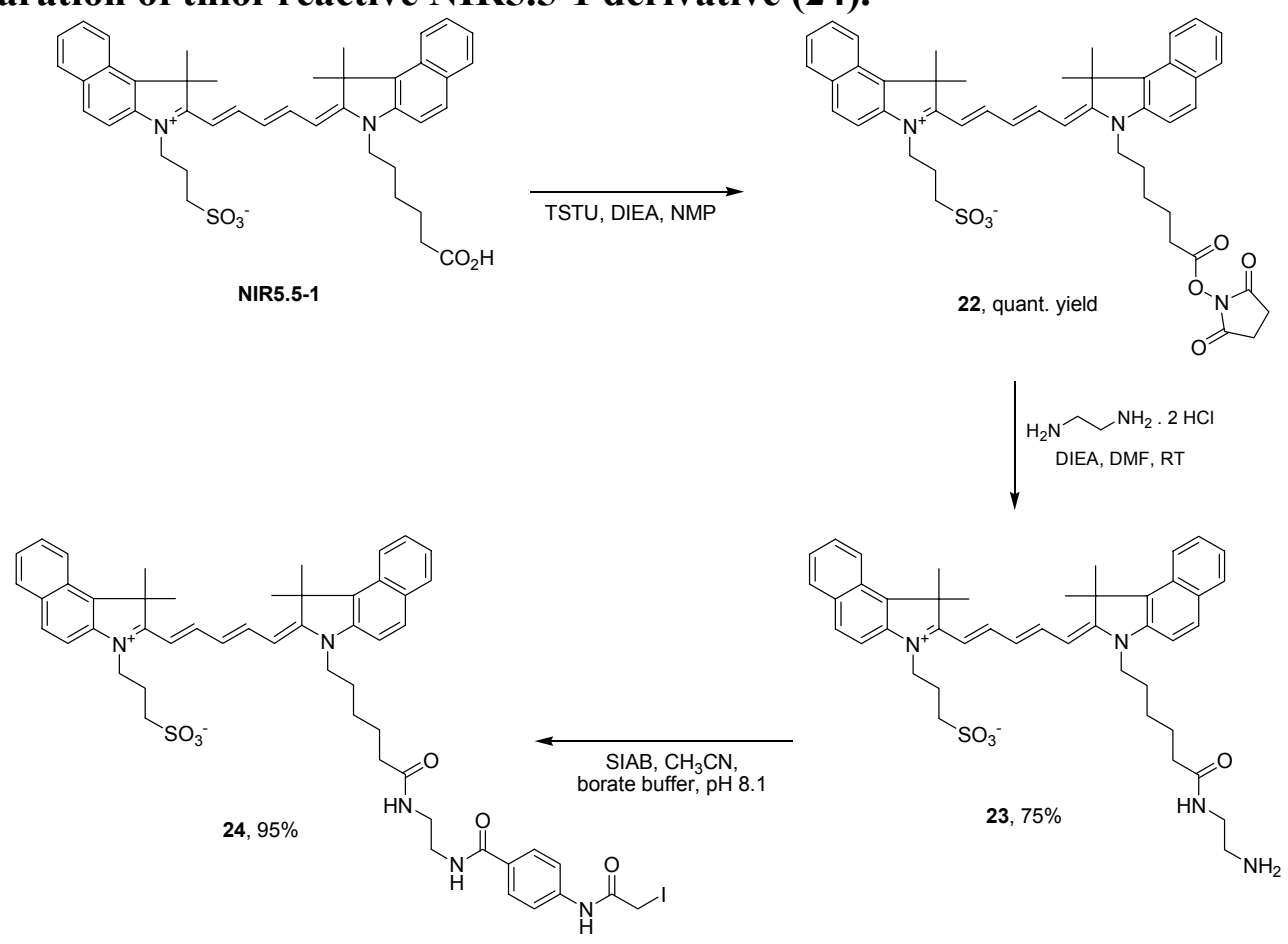

Synthetic reactions used for the preparation of thiol-reactive NIR5.5-1 derivative $\mathbf{2 4}$.

(a) Preparation of NIR5.5-1 carboxylic acid, Succinimidyl Ester 22. Free carboxylic acid dye NIR5.5-1 (6.6 mg, 9.6 $\mu \mathrm{mol})$ was introduced into a Reacti-Vial ${ }^{\mathrm{TM}}$ and dissolved in $140 \mu \mathrm{L}$ of 
dry NMP. $20 \mu \mathrm{L}$ of a solution of TSTU reagent in dry NMP $(2.88 \mathrm{mg}, 9.6 \mu \mathrm{mol})$ and $11.7 \mu \mathrm{L}$ of DIEA $(28.8 \mu \mathrm{mol})$ were added and the resulting reaction mixture was protected from light and stirred at room temperature for $1 \mathrm{~h}$. The reaction was checked for completion by RPHPLC (system A1) and the resulting succinimidyl ester 22 was used without further purification. HPLC (system A1): $t_{\mathrm{R}}=33.6 \mathrm{~min}$ (compared to $t_{\mathrm{R}}=32.6 \mathrm{~min}$ for NIR5.5-1 carboxylic acid).

(b) Synthesis of NIR5.5-1 amine 23. Ethylenediamine dihydrochloride (150 $\mathrm{mg}, 1.152 \mathrm{mmol}$ ) was dissolved in a mixture of deionised water $(0.9 \mathrm{~mL})$ and DMF $(10 \mathrm{~mL})$. The crude reaction mixture containing the succinimidyl ester 22 and a $10 \%$ solution of DIEA in DMF $(0.9 \mathrm{~mL}$, $537 \mu \mathrm{mol})$ were sequentially added and the resulting reaction mixture was was protected from light and stirred at room temperature for $1 \mathrm{~h}$. The reaction was checked for completion by RPHPLC (system A1) and the mixture was evaporated to dryness. The resulting residue was purified by RP-HPLC (system B1, 2 injections). The product-containing fractions were lyophilised to give the NIR5.5-1 amine 23 as a blue amorphous powder (5.2 mg, yield 75\%). HPLC (system A1): $t_{\mathrm{R}}=29.8 \mathrm{~min}$, purity $>95 \%$. MS (MALDI-TOF, positive mode, CHCA matrix): $\mathrm{m} / \mathrm{z} 733.82[\mathrm{M}+\mathrm{H}]^{+}$, calcd exact mass for $\mathrm{C}_{44} \mathrm{H}_{52} \mathrm{~N}_{4} \mathrm{O}_{4} \mathrm{~S} 732.99$.

(c) Preparation of NIR5.5-1 SIAB derivative 24. NIR5.5-1 amine $23(9.6 \mu \mathrm{mol})$ was dissolved in a mixture of $\mathrm{CH}_{3} \mathrm{CN}(250 \mu \mathrm{L})$ and borate buffer $(140 \mu \mathrm{L}, 50 \mathrm{mM}, \mathrm{pH} 8.1)$. A solution of SIAB reagent $(4.14 \mathrm{mg}, 10.3 \mu \mathrm{mol})$ in a mixture of $\mathrm{CH}_{3} \mathrm{CN}(400 \mu \mathrm{L})$ and borate buffer $(350 \mu \mathrm{L})$ was added. The reaction mixture was protected from light and stirred at room temperature for $90 \mathrm{~min}$. The reaction was checked for completion by RP-HPLC (system A1). Finally, the reaction mixture was quenched by dilution with aq. TFA $0.1 \%$ and purified by RP-HPLC (system B2, 2 injections). The product-containing fractions were lyophilised to give the thiol-reactive NIR5.5-1 derivative 24 as a blue amorphous powder $(9.8 \mathrm{mg}$, yield 95\%). HPLC (system A1): $t_{\mathrm{R}}=32.4 \mathrm{~min}$, purity $>95 \%$. MS (MALDI-TOF, positive mode, CHCA matrix): $m / z$ 1020.88 $[\mathrm{M}+\mathrm{H}]^{+}, 1042.86[\mathrm{M}+\mathrm{Na}]^{+}$, calcd exact mass for $\mathrm{C}_{53} \mathrm{H}_{58} \mathrm{IN}_{5} \mathrm{O}_{6} \mathrm{~S}$ 1020.05 .

Synthesis of Ac-Cys(NIR5.5-1)-Asp-Glu-Val-Asp-Lys(NIR7.0-2)-NH 2 (25). Peptide AcCys-Asp-Glu-Val-Asp-Lys(NIR7.0-2)- $\mathrm{NH}_{2} 18(3.4 \mathrm{mg}, 2.3 \mu \mathrm{mol})$ was introduced into a Reacti-Vial $^{\mathrm{TM}}$ and dissolved in $600 \mu \mathrm{L}$ of sodium bicarbonate buffer $(0.1 \mathrm{M}, \mathrm{pH} 8.5) .400 \mu \mathrm{L}$ of a solution of iodoacetyl derivative $24(0.8 \mathrm{mg}, 0.77 \mu \mathrm{mol})$ in DMF was added. The reaction mixture was protected from light and stirred at room temperature for $2 \mathrm{~h}$. The reaction was checked for completion by RP-HPLC (system A2) and purified by RP-HPLC (system B3, 3 injections, $t_{\mathrm{R}}=30.0 \mathrm{~min}$ ). The product-containing fractions were lyophilised to give the peptide Ac-Cys(NIR5.5-2)-Asp-Glu-Val-Asp-Lys(NIR7.0-2)- $\mathrm{NH}_{2} \quad \mathbf{2 5}$ as a blue-green amorphous powder. This fluorogenic caspase-3 substrate was found to be not soluble in aqueous buffers even after conversion into the triethylammonium salt. Consequently, stock solution of 25 was prepared in HPLC grade water (containing 10\% DMSO) and UV-Visible quantification was achieved in EtOH at $\lambda_{\max }$ of the NIR7.0-2 by using the $\varepsilon$ value $171000 \mathrm{M}^{-}$ ${ }^{1} \mathrm{~cm}^{-1}$ (yield after RP-HPLC purification: 24\%). HPLC (system A2): $t_{\mathrm{R}}=41.5 \mathrm{~min}$, purity $>$ 95\%. UV/Visible (water, $25^{\circ} \mathrm{C}$ ): $\lambda_{\max }=646$ (broad) and $801 \mathrm{~nm}$. UV-Visible (EtOH, $25^{\circ} \mathrm{C}$ ): $\lambda_{\max }=682$ and $793 \mathrm{~nm}$. MS (MALDI-TOF, positive mode, CHCA matrix): $\mathrm{m} / \mathrm{z} 1711.16$ $[\mathrm{M}+\mathrm{H}]^{+}, 1734.16[\mathrm{M}+\mathrm{Na}]^{+}, 1753.13[\mathrm{M}+\mathrm{K}]^{+}$, calcd exact mass for $\mathrm{C}_{85} \mathrm{H}_{109} \mathrm{~N}_{13} \mathrm{O}_{21} \mathrm{~S}_{2}$ 1713.02. 
-S2- MALDI-TOF mass spectrum of the fluorogenic substrate of caspase-3 protease $\mathbf{2 5}^{a}$, in the positive mode, $[\mathrm{M}+\mathrm{H}]^{+}: \mathrm{m} / \mathrm{z}$ : calcd $\mathrm{C}_{85} \mathrm{H}_{109} \mathrm{~N}_{13} \mathrm{O}_{21} \mathrm{~S}_{2} 1713.02$ , found 1711.16. Structures of peptide $\mathbf{2 6}$ and thiol NIR dye $\mathbf{2 1}$.

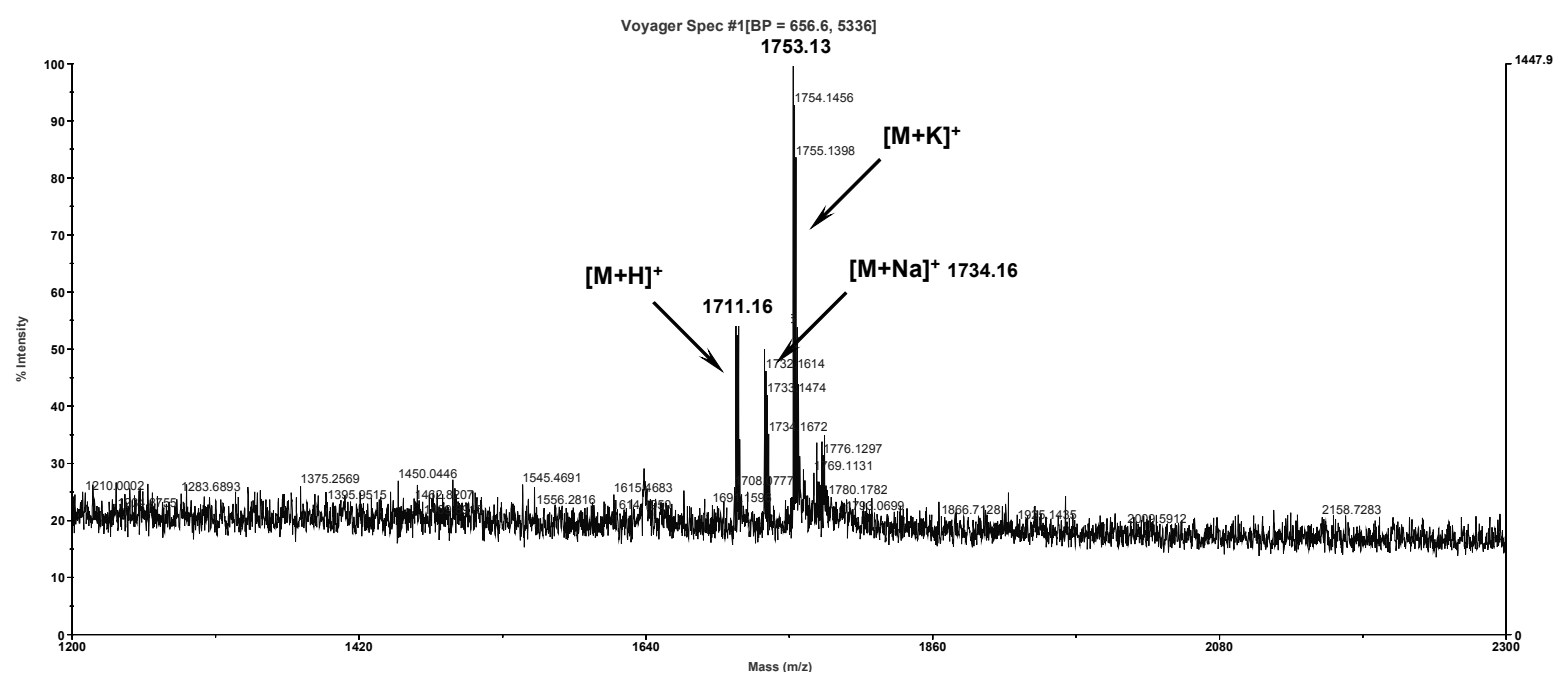

${ }^{a}$ Loss of thiol NIR dye 21 occurred during the ionisation process.
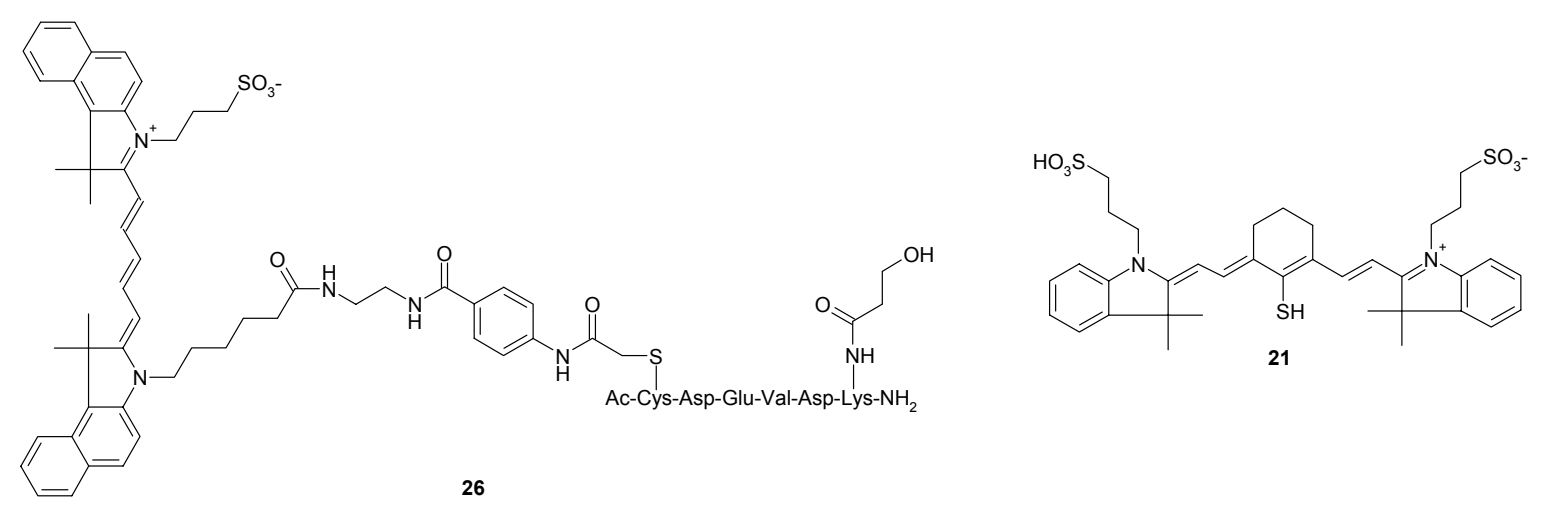

26 
-S3- Absorption spectra of probe 25 at $25^{\circ} \mathrm{C}$ (concentration $2.2 \mu \mathrm{M}$ ). (a) in PBS. (b) in $\mathrm{EtOH}$.
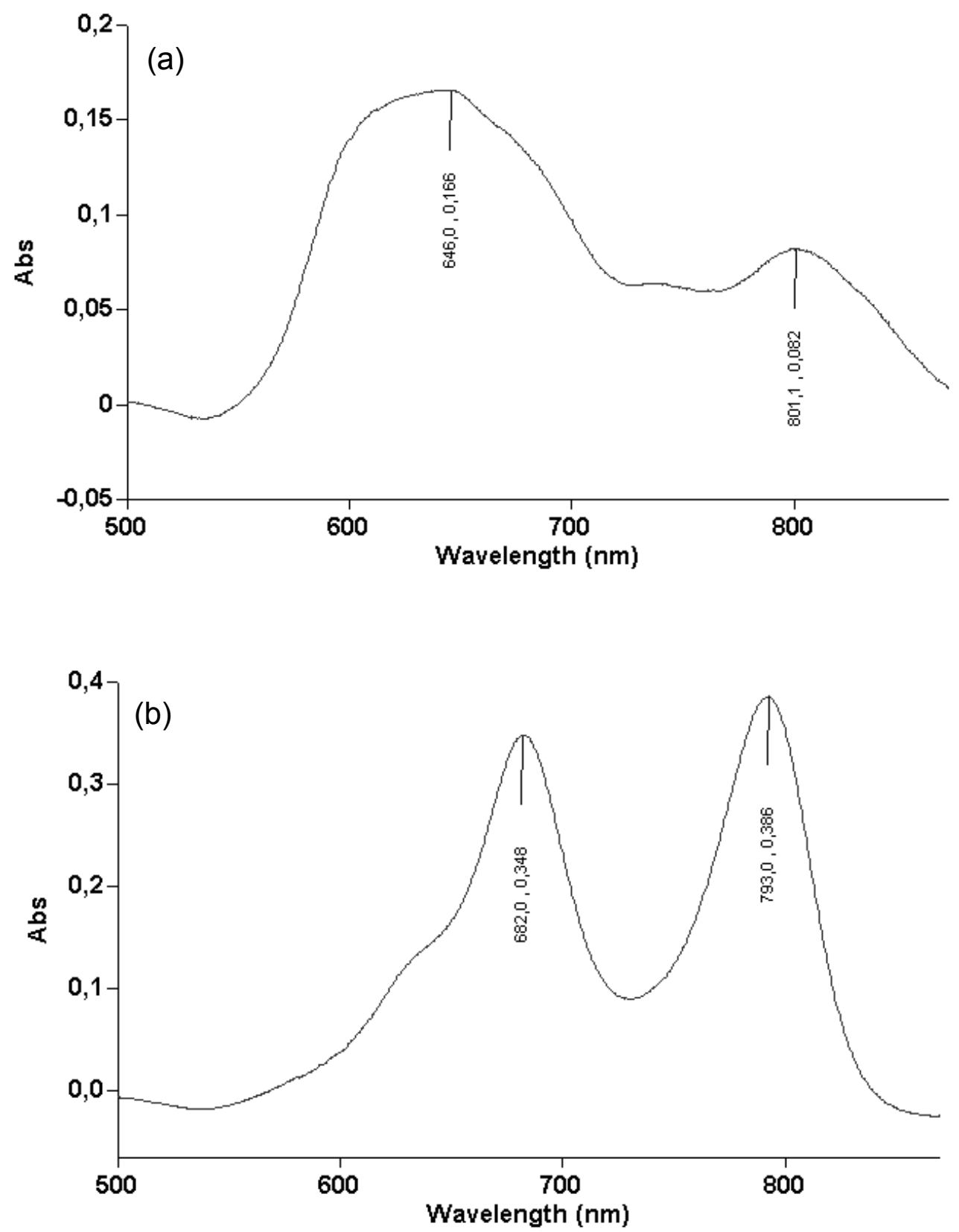
-S4- Emission spectra of probe 25 at $25^{\circ} \mathrm{C}$ (concentration $2.2 \mu \mathrm{M}$ ) (a) Ex. $\lambda=$ $670 \mathrm{~nm}$ (in PBS and EtOH). (b) Ex. $\lambda=750 \mathrm{~nm}$ (in PBS and EtOH).
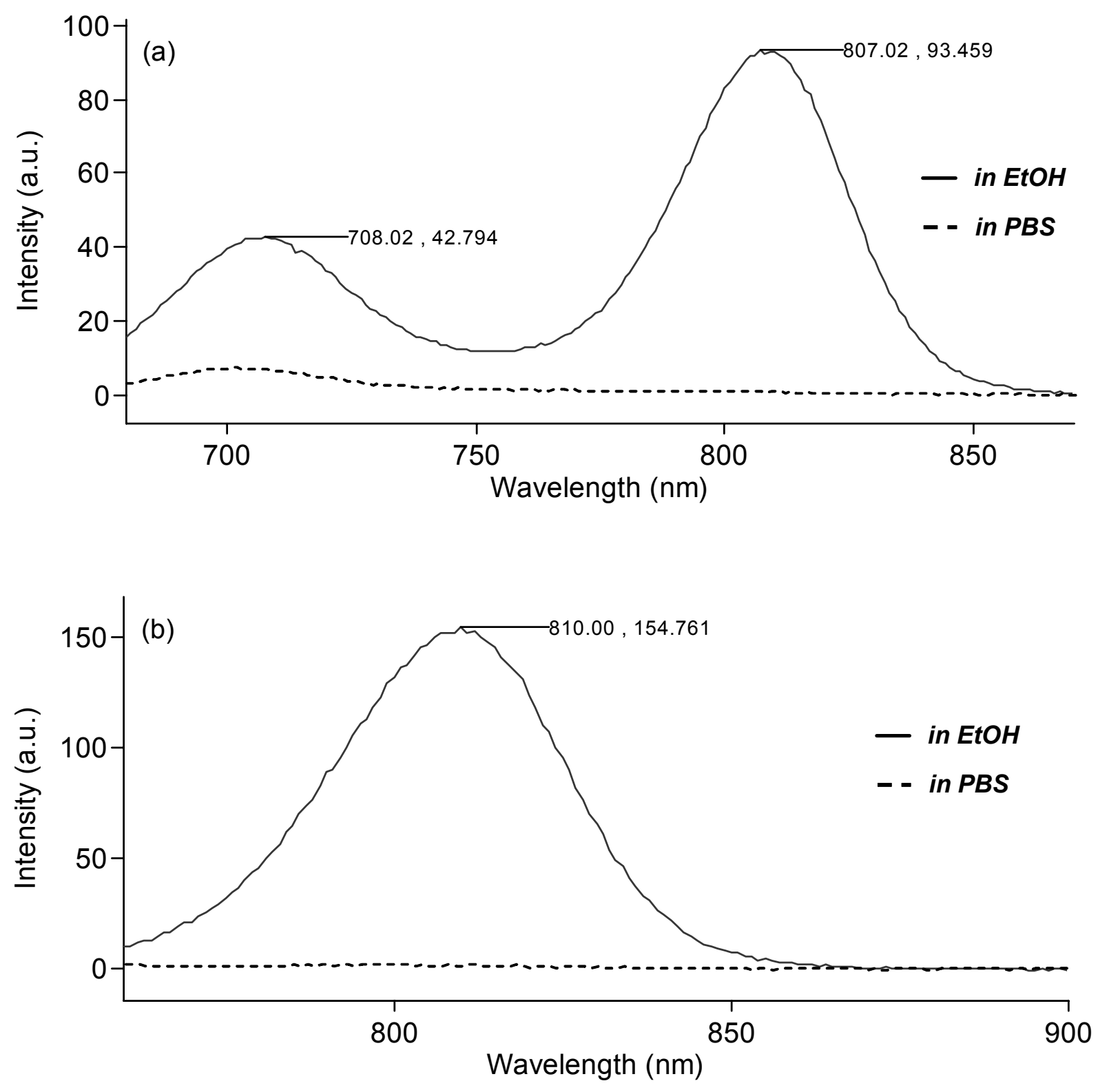
-S5- Emission spectra of probe 19 at $25^{\circ} \mathrm{C}$ (concentration $2.6 \mu \mathrm{M}$ ). Ex. $\lambda=780$ $\mathrm{nm}$ (in PBS and DMSO).

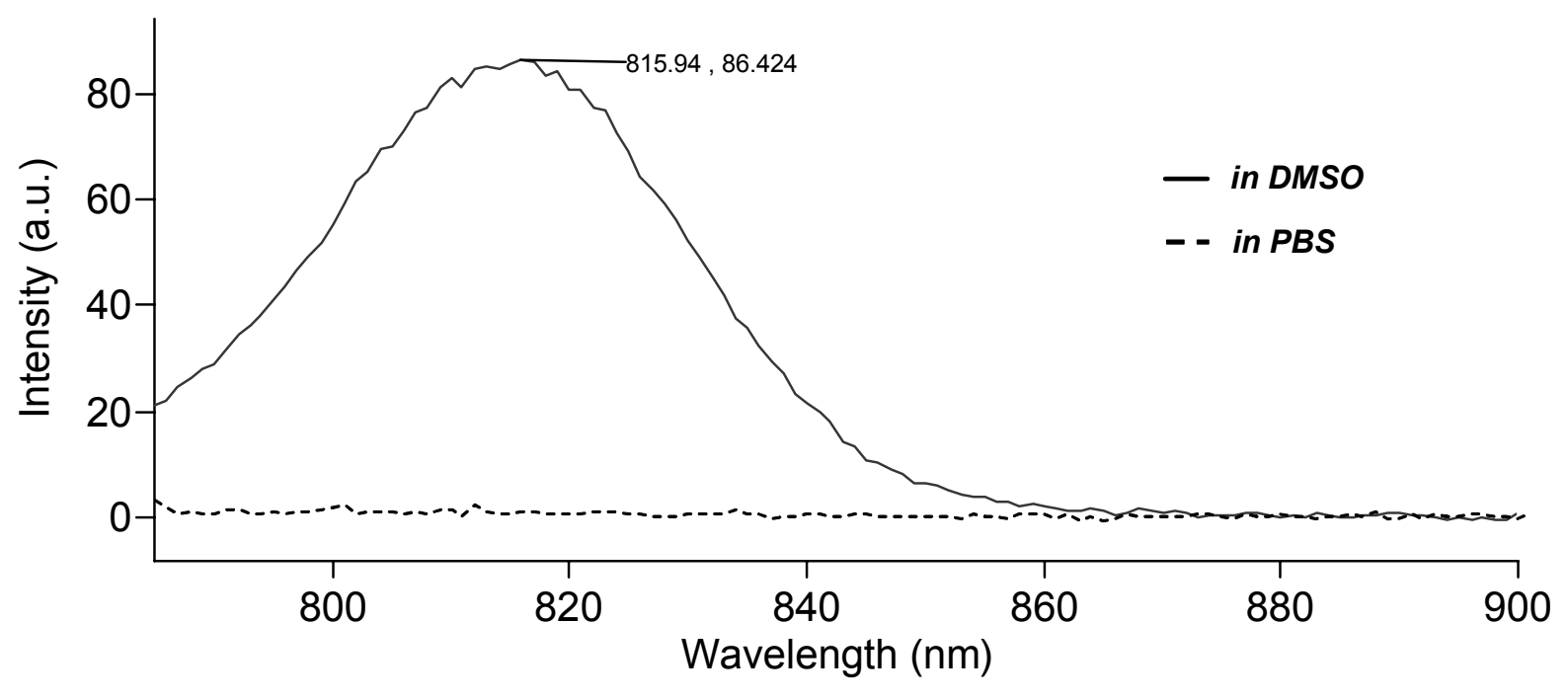


-S6- Fluorescence emission time course of probe 19 (concentration $1.0 \mu \mathrm{M}$ ) with BSA protein $(20 \mu \mathrm{g}$, incubation time $180 \mathrm{~min})$ in caspase assay buffer (100 $\mathrm{mM} \mathrm{NaCl}, 40 \mathrm{mM}$ HEPES, $10 \mathrm{mM}$ DTT, $1 \mathrm{mM}$ EDTA, 10\% (w/v) sucrose and $\left.0.1 \%(\mathrm{w} / \mathrm{v}) \mathrm{CHAPS}, \mathrm{pH} 7.2,37^{\circ} \mathrm{C}\right)$ at $705 \mathrm{~nm}($ Ex. $\lambda=670 \mathrm{~nm})$ and $805 \mathrm{~nm}$ (Ex. $\lambda=770 \mathrm{~nm})$.

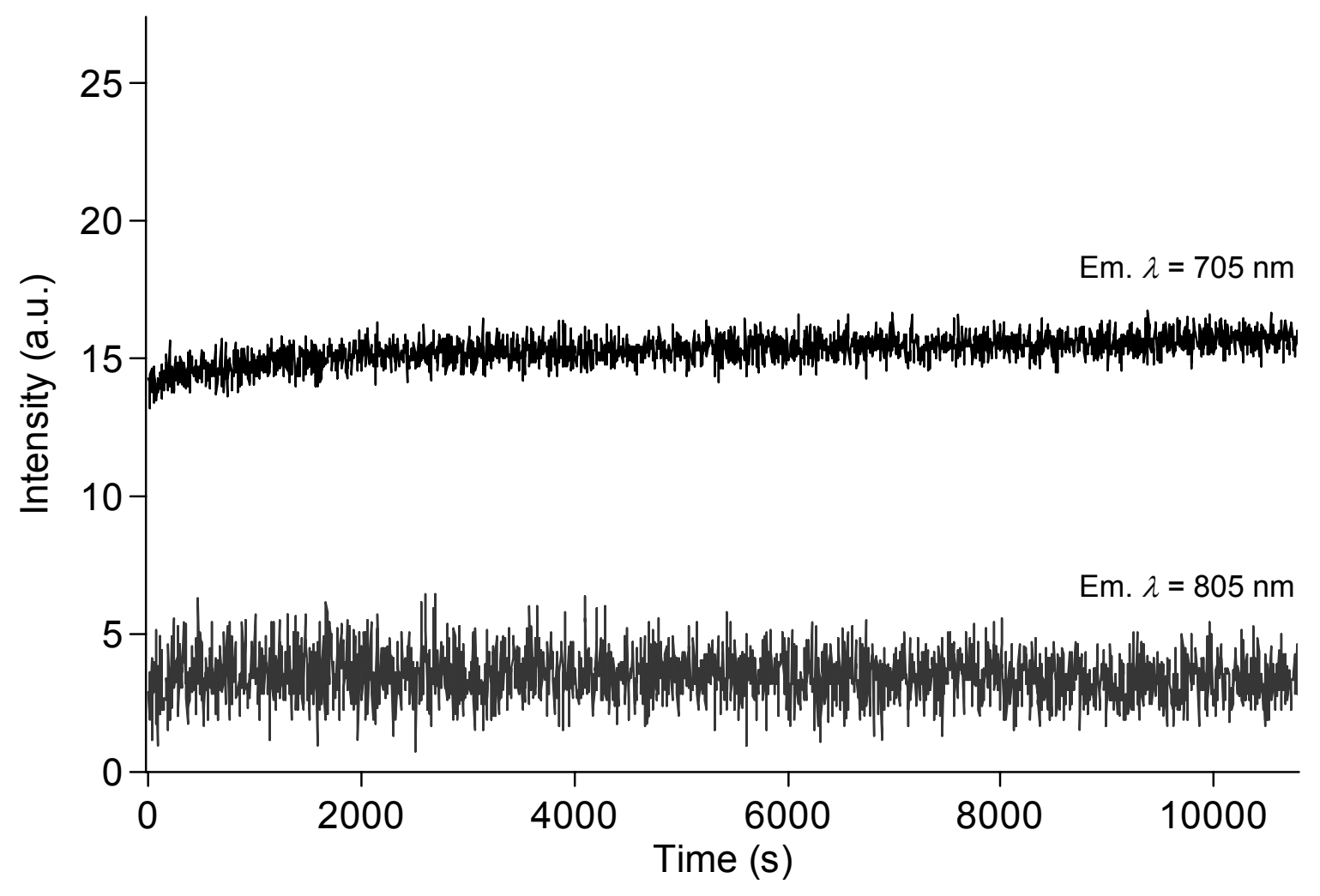

